\title{
The process of setting micronutrient recommendations: a cross-European comparison of nutrition-related scientific advisory bodies
}

\author{
Lada Timotijevic ${ }^{1, *}$, Julie Barnett ${ }^{2}$, Kerry Brown ${ }^{1}$, Richard Shepherd ${ }^{1}$, \\ Laura Fernández-Celemín ${ }^{3}$, Livia Dömölki ${ }^{4}$, Juri Ruprich ${ }^{5}$, Rosalie A Dhonukshe-Rutten ${ }^{6}$, \\ Anne-Mette Sonne ${ }^{7}$, Maria Hermoso ${ }^{8}$, Berthold Koletzko ${ }^{8}$, Lene Frost-Andersen ${ }^{9}$, \\ Arnold Timmer ${ }^{10}$ and Monique M Raats ${ }^{1}$ \\ ${ }^{1}$ Food, Consumer Behaviour and Health Research Centre, School of Human Sciences, University of Surrey, \\ Guildford GU1 1TR, UK: ${ }^{2}$ Department of Information Systems and Computing, Brunel University, Uxbridge, UK: \\ ${ }^{3}$ European Food Information Council (EUFIC), Brussels, Belgium: ${ }^{4}$ National Association for Consumer Protection \\ in Hungary, Budapest, Hungary: ${ }^{5}$ Department of Food Safety and Nutrition, National Institute of Public Health, \\ Brno, Czech Republic: ${ }^{6}$ Division of Human Nutrition, Wageningen University, Wageningen, The Netherlands: \\ ${ }^{7}$ MAPP - Centre for research on customer relations in the food sector, University of Aarhus, Aarhus, Denmark: \\ ${ }^{8}$ Division of Metabolic Diseases and Nutrition, Ludwig-Maximilians University of Munich, Munich, Germany: \\ ${ }^{9}$ Department of Nutrition, Institute of Basic Medical Sciences, University of Oslo, Oslo, Norway: ${ }^{10}$ UNICEF \\ Headquarters, New York, NY, USA
}

Submitted 22 October 2009: Accepted 30 June 2010: First published online 23 September 2010

\begin{abstract}
Objective: To examine the workings of the nutrition-related scientific advisory bodies in Europe, paying particular attention to the internal and external contexts within which they operate.

Design: Desk research based on two data collection strategies: a questionnaire completed by key informants in the field of micronutrient recommendations and a case study that focused on mandatory folic acid (FA) fortification.

Setting: Questionnaire-based data were collected across thirty-five European countries. The FA fortification case study was conducted in the UK, Norway, Denmark, Germany, Spain, Czech Republic and Hungary.

Results: Varied bodies are responsible for setting micronutrient recommendations, each with different statutory and legal models of operation. Transparency is highest where there are standing scientific advisory committees (SAC). Where the standing $\mathrm{SAC}$ is created, the range of expertise and the terms of reference for the SAC are determined by the government. Where there is no dedicated SAC, the impetus for the development of micronutrient recommendations and the associated policies comes from interested specialists in the area. This is typically linked with an ad boc selection of a problem area to consider, lack of openness and transparency in the decisions and over-reliance on international recommendations.

Conclusions: Even when there is consensus about the science behind micronutrient recommendations, there is a range of other influences that will affect decisions about the policy approaches to nutrition-related public health. This indicates the need to document the evidence that is drawn upon in the decisions about nutrition policy related to micronutrient intake.
\end{abstract}

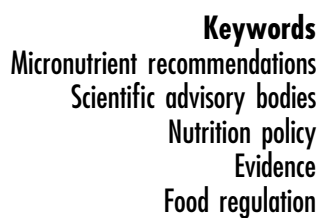

Currently, most countries in Europe establish their own nutrient recommendations, and there is large heterogeneity in the recommendations within Europe ${ }^{(1-3)}$. The European Food Safety Authority (EFSA) is in the process of reviewing and updating the last report on recommended nutrient and energy intakes for the European Union (EU) population published in 1993, prepared by the Scientific Committee on Food ${ }^{(4)}$. Variability is partly due to the use of different approaches (e.g. health outcomes and methods used when data are missing for sub-populations), changes over time in the approach to establishing recommendations and/or data used $^{(3)}$ and the uncertain nature of many scientific elements ${ }^{(5)}$. The background information provided in the recommendation reports lacks transparency as it is not possible to disentangle the relative contribution of different aspects of evidence. Because of this lack of transparency it is 
often difficult to track why there is heterogeneity in micronutrient recommendations. This lack of transparency then leads to perceived inconsistency, perceived lack of objectivity, complexity in presentation, lack of clarity, difficulty in implementation, decreased chances of reliability and it hides research gaps ${ }^{(6,7)}$.

Variability may also be due to the variable influence of international organisations such as the WHO, FAO or EFSA. Although the WHO and FAO are mandated by Member States to develop policy and programme guidance on health, food and agriculture-related matters, including nutrition recommendations, such guidance is freely accepted by countries. The existing significant scientific activity at the national level (e.g. Nordic countries Denmark, Finland, Iceland, Norway and Sweden, UK, DACH countries - Germany, Austria and Switzerland) as well as the historical links that exist between some national scientific communities can explain the variability in the acceptance of the international micronutrient recommendations.

Scientific advisory bodies (SAB) are groups through which expert advice enters the political process and can establish institutions, short-term commissions, ad hoc and standing committees and an informal network of experts ${ }^{(8)}$. Their key role is to feed technical recommendations into the policy development process. Evidence suggests that SAB play a crucial role in advising government on development and implementation of nutrition policies: WHO has noted the possible link between the existence of SAB and the degree to which nutrition policies are developed and implemented $^{(9)}$. There is, however, little research that seeks to explain why this might be the case. The way in which nutrition-related SAB operate in Europe, and how they input into public health nutrition policy related to micronutrient recommendations, is the focus of the current paper.

\section{The changing policy context}

Scientific expertise often underlies evidence-based policy making, as it is used to make decisions more rational, justifiable and effective. It may also facilitate greater public acceptance, and is thus a valuable tool in policy makers' efforts to manage accountability and justify value-based decisions $^{(9-11)}$. Recent emphasis on evidence-based policy, the proliferation of governance bodies whose job is to monitor the evidence base (e.g. EFSA) and 'knowledge management systems' signal a shift in policy making towards greater reliance on scientific expertise ${ }^{(12)}$.

Although SAB play a crucial role in informing and providing a rationale for policy decisions, the recent trajectory of their involvement in government decision making has been characterised by a shift in their role and relationship with policy decision makers, from a closed, instrumental approach to policy (i.e. science-driven) to the emphasis on openness (i.e. admission into policy considerations of different forms of evidence, including scientific) and transparency (i.e. more clarity about the way in which decisions have been achieved ${ }^{(13-15)}$ ). Following a series of high-profile failures of scientific advisors and government officials to protect public interest in assessing and managing health and environmental risks (e.g. BSE), the recognition that uncertainty is inherent to scientific judgement and that subjective and objective elements of expert decision making are difficult to disentangle, there are now public and policy pressures for the democratisation of expertise ${ }^{(13,16,17)}$. Various policy documents $^{(12,18-20)}$ have indicated a need for greater transparency in the workings of SAB.

In addition to transparency in the decision-making processes of SAB, there is also a call for an increased openness to the inclusion of stakeholder perspectives. Within the EU, there has been a move towards pragmatic management of multiple views and perspectives and co-production of policy decisions, so that they take into account the views of the various stakeholders ${ }^{(18,21)}$, while science itself is expected to be increasingly utilitarian in the way research questions are framed and solutions sought, with the expectations of it being informed by and responding to the views of lay citizens and society at large ${ }^{(9,22)}$. As part of the call for the democratisation of expertise, recent academic focus has been on the examination of the workings of expert advisory bodies ${ }^{(9,15,23-25)}$. The main streams of empirical work around SAB are:

- knowledge gathering/formation and expert decisions $^{(9,24-26)}$; and

- knowledge transfer - the way in which expert and policy worlds meet and influence each other ${ }^{(27,28)}$.

\section{Knowledge gatbering and formation}

The way in which expertise is defined and SAB are structured determine how a problem is framed, which in turn influences the decisions around the inclusion or exclusion of particular perspectives and the way in which facts are selected and interpreted and conclusions are drawn $^{(10,23,29,30)}$. The nature and source of expertise may also be significant factors in whether scientific advice is taken up in the policy-making process ${ }^{(23)}$. Traditionally, SAB-related expertise has been defined in terms of an individual expert's (i) qualifications, knowledge and experience in their chosen field; (ii) 'eminence' or 'authority' as a trusted source of science in communication with wider society; and/or (iii) their institutional affiliation $^{(24,30,31)}$.

With the crisis of confidence in science, academic attention has turned towards the nature of decision making in SAB, including the way in which experts within SAB deal with scientific uncertainties, scientific controversies and pressures for consensus ${ }^{(15,32)}$ and the variety of influences on expert advice ${ }^{(12)}$. From a sociological perspective it is recognised that scientific decision 
making is deeply intertwined with the context in which it operates ${ }^{(23,32)}$. The notion of co-production of knowledge, which is concerned with the way in which science and society shape each other, has been put forward as a useful framework for the study of decision making in $\mathrm{SAB}^{(33)}$, leading to calls for various forms of knowledge (e.g. technical, lay) being granted equality in the formulation and deliberation around scientific issues ${ }^{(34)}$. Some of the issues discussed include how to achieve engagement with the public ${ }^{(34,35)}$, the notions of 'opening up' of expert considerations and the questioning of the boundaries between lay and expert perspectives ${ }^{(36)}$. However, many authors have recognised the inherent tension between different forms of knowledge within $\mathrm{SAB}$ and an unequal balance of power being assigned to representatives of lay and technical knowledge on these committees $^{(37)}$

Applying these ideas to the evaluation of the existing $\mathrm{SAB}$, another line of research has examined the stages of decision making and demonstrated how different types of knowledge and expertise input can inform decisions at each stage ${ }^{(38-40)}$. Typical stages include risk assessment, risk management and risk communication ${ }^{(12,38)}$. Decision making, however, is largely confined to experts and professional risk managers, with little input from other interested parties, including citizens ${ }^{(12)}$. In recognition of this, there have been attempts to develop a tool to guide policy makers and scientists in making decisions about when scientific decision making should be opened up and when other stakeholders should be involved $^{(41,42)}$.

\section{Knowledge transfer}

Much literature examines how SAB communicate with policy decision makers ${ }^{(15,23,39,43)}$ and takes into account both the internal context in which decisions are made and the external context that shapes this ${ }^{(39,43)}$. The internal context, which can be changed and controlled from within the SAB and by their commissioners, includes the way in which expertise is defined, how representative $\mathrm{SAB}$ are, the degree of openness to stakeholder input in framing, analysing and formulating solutions to an issue, and transparency of the way in which decisions are made. External context amounts to the environment in which a decision is applied and cannot be easily altered or controlled. Crucially, SAB are expected to maintain independence from the bodies they advise, although in practice, this remains a challenge ${ }^{(22)}$. Given the unique position of $\mathrm{SAB}$ as intermediaries between science and policy, they have been a fertile ground for the study of the boundary between politics and science, its negotiation and the degree to which the two permeate each other ${ }^{(9,44)}$. Whether scientific advice is salient, credible or legitimate is considered an important determinant of influence ${ }^{(45)}$. However, these criteria of influence as well as SAB decision-making processes and outcomes will be determined by the external context in which SAB operate, and include ideological, socio-political, economic and legal issues ${ }^{(43)}$.

The present paper aims to examine the workings of nutrition-related $\mathrm{SAB}$ in the process of setting recommendations for folic acid (FA), through a comparative analysis of the process of setting micronutrient recommendations across Europe, paying particular attention to the internal and external contexts within which the $\mathrm{SAB}$ operate.

\section{Methods}

\section{Questionnaire}

Questionnaires were completed by key informants in thirty-five European countries/regions. The main objectives across countries were:

- to collate all the existing current micronutrient recommendations and describe the process of deriving nutrition recommendations and their use in nutrition policies; and

- for each micronutrient, to identify the policies adopted as a result of recommendations.

Data were collected on: 'structure of the committee' (e.g. type of expertise, selection criteria); 'process of scientific decision making' (for each micronutrient: nature of scientific evidence considered, type of recommendations, health endpoints, population groups, vulnerable groups, how recommendations have informed the development of food-based dietary guidelines (FBDG)); and 'the way in which science resonates with policy' (i.e. policy options recommended by SAB setting Nutrient Reference Values (NRV) and policy applications, i.e. actual policies adopted by governing bodies responsible for these).

\section{Case study}

An in-depth case study was conducted in seven countries varying in length of public health nutrition tradition, level of centralisation and diversity of institutions involved in the governance of nutrition, and extent of participatory democracy: Czech Republic, Denmark, England, Germany, Hungary, Norway and Spain. The main objectives were:

- to understand the process from science to policy, and the determinants of variations in this process across nations/regions, policy applications and micronutrients, with a specific focus on FA; and

- to identify the way in which scientific, policy and consumer issues interact throughout this process.

Information was obtained on: (i) the degree of transparency of decision making and its openness to public scrutiny; (ii) contextual characteristics, i.e. the institutional, administrative and political context (e.g. how food and policy were/are conceptualised, the names of key 
stakeholders); (iii) the generic process of setting up micronutrient recommendations (e.g. who is in charge, triggers for the development of recommendations, who is invited to take part, what is the type of scientific data considered, the degree of scientific certainty/controversy); and (iv) the process from science to policy application for FA. An assessment was made about the public availability of literature and documentation on the workings of the institutions responsible for the development of micronutrient recommendations, public and stakeholder involvement and nutrition policy processes, indicating the degree to which participatory democracy has evolved and the level of transparency and openness in the processes of science and policy in each of the countries in question.

\section{Results}

\section{Institutional capacity}

The questionnaire data indicate that in approximately half of the countries (eighteen out of thirty-five), the final responsibility for setting micronutrient recommendations rests with government departments (Table 1). Recommendations are supported by one or a combination of scientific bodies - scientific advisory committees (often called 'advisory councils') or SAC (ten countries), public health institutes (fifteen countries), nutrition societies (five countries). The EU's micronutrient recommendations were set by EFSA and supported by SAC and the WHO/FAO recommendations by a European expert consultation.

Where SAC exist, there are either standing committees providing continual advice to government, or they are formed on an ad hoc basis. Standing SAC often form subcommittees or working groups to deal with specific issues of importance, mainly at the request of the government, such as the need to develop recommendations for specific micronutrients (e.g. iodine) or population groups (e.g. infants).

In some countries, the decisions about recommendations and nutritional matters rest with established research centres, and sometimes with nutrition societies. Each of the three types of SAB - SAC (e.g. the UK, Nordic countries), public health institutes (e.g. Spain, Czech Republic, Hungary) and nutritional societies (e.g. DACH) - are entities that substantially differ in their statutory responsibilities and operate within diverse regulatory frameworks (e.g. funding sources). Members of the SAC are appointed by authorities (usually government departments) on the basis of their individual expertise, eminence or affiliation with an eminent institution, although potential members often have to apply to be considered for SAC. Nutrition societies are membership organisations whereby inclusion is based on self-selection and satisfaction of membership criteria, whereas research centres/institutes, like universities, are employers.
A range of criteria was mentioned within the questionnaire as the basis of the selection of members of various committees and societies (Table 1). Almost all countries, as well as the EU and WHO/FAO, mentioned individual expertise as an important criterion for the selection of persons involved in setting micronutrient recommendations, whereas institutional authority (fifteen countries), representation of a sector (e.g. industry, academia, consumer - nine countries) and forms of knowledge (six countries) were other - albeit overlapping - common criteria. Most countries based their selection of persons involved in setting micronutrient recommendations on one (typically individual expertise) or two criteria (e.g. individual expertise plus institutional authority).

The type of expertise that is selected on SAC is similar across Europe. Most countries mention at least three of the following fields of expertise: nutrition, (public) health, medicine, biochemistry, food technology, epidemiology, food hygiene and toxicology. In several countries (e.g. UK) lay or consumer representatives are included in the SAC or the working groups. The questionnaire data do not indicate that there are variations across countries in the propensity to recommend a policy option, based on the type of SAB responsible. However, it could be expected that policy recommendations (options for policy) made by each of the respective SAB (i.e. SAC, institutes and nutrition societies) would 'resonate' to varying degrees with the government, stakeholders and the public. The rationale for this is partly based on inferences about the independence of SAB, their eminence/credibility, their legitimacy (based on representativeness, selection criteria) and salience ${ }^{(9,45)}$. The differences might be particularly notable in the way in which recommendations for the enforcement-type policy instruments (e.g. mandatory fortification, legislation on micronutrient composition in food products and labelling) are taken up by the respective authorities. This will be explored in the case study.

\section{A case study of mandatory folic acid fortification}

Knowledge of the origins of the recommendations is important as they indicate what possible frameworks of decision making are operational within the SAB (from framing of the problem to the possible solutions). Thus, although the UK's Scientific Advisory Committee for Nutrition (SACN), the German Nutrition Society (DGE) in DACH countries and the Nordic Nutrition Recommendations (NNR; the Nordic countries' National Nutrition Council (NNC), now the Nordic Directorate of Health $(\mathrm{NDH})$ ) conduct their own systematic reviews of all the available data (in the problem area specified by their terms of reference, such as a specific micronutrient or the nutrition for a particular population group), identifying possible areas of uncertainties, the weaknesses of science and actively engaging in problem delineation, this does not seem to be the case in Czech Republic and Hungary. Hungarian recommendations are adopted from the US, 
Table 1 The type and nature of the body responsible for setting micronutrient recommendations

Involvement in setting recommendations

\begin{tabular}{|c|c|c|c|c|c|c|}
\hline $\begin{array}{l}\text { Country/ } \\
\text { organisation/region }\end{array}$ & Body responsible & Type of body & Responsible since & Persons involved & Selection criteria & Field of expertise \\
\hline Albania & $\begin{array}{l}\text { Ministry of Health, supported by the } \\
\text { University Hospital, Agrofood } \\
\text { Department of Agricultural } \\
\text { University of Tirana and FAO local } \\
\text { office }\end{array}$ & $\begin{array}{l}\text { Governmental, } \\
\text { scientific }\end{array}$ & No data available & Three & $\begin{array}{l}\text { Individual expertise, institutional } \\
\text { authority }\end{array}$ & $\begin{array}{l}\text { Nutrition, public health, } \\
\text { biochemistry, food technology }\end{array}$ \\
\hline Belgium & $\begin{array}{l}\text { National Health Council (Hoge } \\
\text { Gezondheidsraad) }\end{array}$ & $\begin{array}{l}\text { Governmental, } \\
\text { working group }\end{array}$ & $\begin{array}{l}1997 \text { (first } \\
\text { publication) }\end{array}$ & Eight & Individual expertise & No data available \\
\hline $\begin{array}{l}\text { Federation of } \\
\text { Bosnia and } \\
\text { Herzegovina }\end{array}$ & Not defined & $\begin{array}{l}\text { Most probably } \\
\text { nutrition society or } \\
\text { medical academic } \\
\text { group }\end{array}$ & No data available & No data available & Individual expertise & $\begin{array}{l}\text { Medical doctors, specialised in } \\
\text { hygiene }\end{array}$ \\
\hline Republika Srpska & $\begin{array}{l}\text { Ministry of Health and Social Welfare, } \\
\text { supported by the Public Health } \\
\text { Institute and health centres }\end{array}$ & $\begin{array}{l}\text { Public Health Institute: } \\
\text { independent } \\
\text { scientific advisory } \\
\text { body }\end{array}$ & 2003 & Five & $\begin{array}{l}\text { Individual expertise, institutional } \\
\text { authority }\end{array}$ & $\begin{array}{l}\text { Nutrition, public health, } \\
\text { biochemistry, medicine, } \\
\text { toxicology, epidemiology, food } \\
\text { technology }\end{array}$ \\
\hline Bulgaria & $\begin{array}{l}\text { Ministry of Health, supported by the } \\
\text { National Centre of Public Health } \\
\text { Protection }\end{array}$ & Governmental & 1980 & Eight & $\begin{array}{l}\text { Individual expertise, different } \\
\text { forms of knowledge }\end{array}$ & $\begin{array}{l}\text { Nutrition, public health, } \\
\text { biochemistry, medicine, } \\
\text { toxicology, epidemiology }\end{array}$ \\
\hline Croatia & $\begin{array}{l}\text { Ministry of Health and Social } \\
\text { Welfare }\end{array}$ & Governmental & No data available & Eleven & $\begin{array}{l}\text { Individual expertise, institutional } \\
\text { authority, specific sector, } \\
\text { different forms of knowledge }\end{array}$ & $\begin{array}{l}\text { Nutrition, public health, } \\
\text { biochemistry, medicine, } \\
\text { toxicology, epidemiology }\end{array}$ \\
\hline Czech Republic & $\begin{array}{l}\text { Ministry of Health, Department of } \\
\text { Public Health, supported by the } \\
\text { Scientific Committee for Food - } \\
\text { iodine }\end{array}$ & $\begin{array}{l}\text { Governmental, } \\
\text { working group for } \\
\text { iodine }\end{array}$ & 1995 & Eight (self-selected) & $\begin{array}{l}\text { Range of stakeholders included, } \\
\text { based on individual expertise } \\
\text { and sector }\end{array}$ & $\begin{array}{l}\text { Nutrition, toxicology, chemistry, } \\
\text { risk assessment }\end{array}$ \\
\hline DACH countries & $\begin{array}{l}\text { German Nutrition Society, Austrian } \\
\text { Nutrition Society, Swiss Society } \\
\text { for Nutrition Research and Swiss } \\
\text { Nutrition Association }\end{array}$ & Nutrition society & $\begin{array}{l}1992 \text { (previous } \\
\text { publication) }\end{array}$ & $\begin{array}{l}\text { Six (plus forty-one } \\
\text { contributors) } \\
\text { selected by the } \\
\text { nutrition society }\end{array}$ & $\begin{array}{l}\text { Individual expertise } \\
\quad \text { (experimental and scientific) }\end{array}$ & Nutrition, food, biochemistry \\
\hline Estonia & $\begin{array}{l}\text { Ministry of Social Affairs, supported } \\
\text { by National Institute for Health } \\
\text { Development }\end{array}$ & $\begin{array}{l}\text { Governmental, } \\
\text { scientific }\end{array}$ & No data available & No data available & $\begin{array}{l}\text { Individual expertise } \\
\text { (scientific), institutional } \\
\text { authority }\end{array}$ & $\begin{array}{l}\text { Nutrition, public health, } \\
\text { biochemistry, medicine, } \\
\text { epidemiology, food } \\
\text { technology }\end{array}$ \\
\hline France & $\begin{array}{l}\text { French Food Safety Agency (Afssa), } \\
\text { former National Centre for Studies } \\
\text { and Recommendations on Nutrition } \\
\text { and Diet (CNERNA) }\end{array}$ & Independent body & 1999 & 200 & $\begin{array}{l}\text { Individual expertise, different } \\
\text { forms of knowledge (from } \\
\text { national community) }\end{array}$ & $\begin{array}{l}\text { Nutrition, public health, } \\
\text { biochemistry, medicine, } \\
\text { epidemiology }\end{array}$ \\
\hline Greece & $\begin{array}{l}\text { Ministry of Health and Social Welfare, } \\
\text { supported by Hellenic National } \\
\text { Nutrition Policy Committee }\end{array}$ & $\begin{array}{l}\text { Governmental, } \\
\text { committee }\end{array}$ & 2002 & No data available & No data available & No data available \\
\hline Hungary & $\begin{array}{l}\text { Ministry of Health, supported by the } \\
\text { National Institute of Food Safety } \\
\text { and Nutrition }\end{array}$ & $\begin{array}{l}\text { Governmental, } \\
\text { working group }\end{array}$ & No data available & Twenty-five & Individual expertise & Nutrition, medicine \\
\hline Ireland & Food Safety Authority of Ireland & $\begin{array}{l}\text { Working group of } \\
\text { independent and } \\
\text { scientific body }\end{array}$ & 1996 & Four & Individual expertise & Clinical medicine, nutrition \\
\hline
\end{tabular}




\begin{tabular}{|c|c|c|c|c|c|c|}
\hline \multirow{2}{*}{$\begin{array}{l}\text { Country/ } \\
\text { organisation/region }\end{array}$} & \multicolumn{6}{|c|}{ 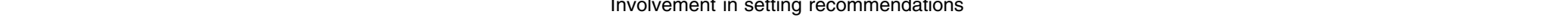 } \\
\hline & Body responsible & Type of body & Responsible since & Persons involved & Selection criteria & Field of expertise \\
\hline Italy & $\begin{array}{l}\text { Italian Society of Human Nutrition } \\
\text { (SINU), supported by the National } \\
\text { Research Institute on Food and } \\
\text { Nutrition (INRAN) }\end{array}$ & $\begin{array}{l}\text { Nutrition society } \\
\text { (scientific with links } \\
\text { to governmental } \\
\text { bodies) }\end{array}$ & 1977 & $\begin{array}{l}\text { Four working groups, } \\
\text { each with eight to } \\
\text { ten members }\end{array}$ & $\begin{array}{l}\text { Individual expertise, institutional } \\
\text { authority, specific sector }\end{array}$ & $\begin{array}{l}\text { Nutrition, public health, } \\
\text { biochemistry, medicine, } \\
\text { epidemiology, food } \\
\text { technology }\end{array}$ \\
\hline Latvia & $\begin{array}{l}\text { Ministry of Health, supported by the } \\
\text { Latvian Food Centre and Nutrition } \\
\text { Council }\end{array}$ & $\begin{array}{l}\text { Governmental, } \\
\text { probably individual } \\
\text { experts or working } \\
\text { group }\end{array}$ & No data available & No data available & $\begin{array}{l}\text { Individual expertise, institutional } \\
\text { authority, specific sector }\end{array}$ & $\begin{array}{l}\text { Nutrition, public health, } \\
\text { biochemistry, medicine, food } \\
\text { technology }\end{array}$ \\
\hline Lithuania & $\begin{array}{l}\text { Ministry of Health, supported by } \\
\text { Food and Nutrition Scientific } \\
\text { Council, National Nutrition Centre } \\
\text { and Medical Faculty of Vilnius } \\
\text { University }\end{array}$ & $\begin{array}{l}\text { Governmental, } \\
\text { scientific }\end{array}$ & 2003 & Four & $\begin{array}{l}\text { Individual expertise, } \\
\text { specific sector }\end{array}$ & $\begin{array}{l}\text { Nutrition, public health, } \\
\text { biochemistry, medicine, } \\
\text { epidemiology, food } \\
\text { technology }\end{array}$ \\
\hline Montenegro & $\begin{array}{l}\text { No body responsible for setting } \\
\text { recommendations }\end{array}$ & $\mathrm{N} / \mathrm{A}$ & N/A & $\mathrm{N} / \mathrm{A}$ & $\mathrm{N} / \mathrm{A}$ & $\mathrm{N} / \mathrm{A}$ \\
\hline Netherlands & $\begin{array}{l}\text { Ministry of Health, supported by } \\
\text { The National Health Council } \\
\text { (TNHC) }\end{array}$ & $\begin{array}{l}\text { Governmental, TNHC } \\
\text { is an independent } \\
\text { scientific advisory } \\
\text { body }\end{array}$ & 1992 & Thirty-eight & $\begin{array}{l}\text { Individual expertise } \\
\text { (independent experts) }\end{array}$ & $\begin{array}{l}\text { Nutrition, public health, } \\
\text { biochemistry, medicine, } \\
\text { epidemiology }\end{array}$ \\
\hline Nordic countries & $\begin{array}{l}\text { Nordic Committee of Senior Officials } \\
\text { on Food Issues, EK-Livs., } \\
\text { supported by the Working Group on } \\
\text { Diet and Nutrition (NKE) }\end{array}$ & $\begin{array}{l}\text { Project group } \\
\text { nominated by NKE }\end{array}$ & 2000 & $\begin{array}{l}\text { Thirty (selected by } \\
\text { government) }\end{array}$ & $\begin{array}{l}\text { Individual expertise } \\
\text { (scientific), institutional } \\
\text { authorities }\end{array}$ & $\begin{array}{l}\text { Nutrition, public health, } \\
\text { medicine, toxicology, } \\
\text { epidemiology (Iceland: } \\
\text { nutrition and health) }\end{array}$ \\
\hline Poland & $\begin{array}{l}\text { Ministry of Health, supported by the } \\
\text { National Food and Nutrition } \\
\text { Institute, Warsaw }\end{array}$ & Governmental & 1963 & Five & $\begin{array}{l}\text { Individual expertise } \\
\text { (experience), institutional } \\
\text { authority (long-term } \\
\text { employment), specific sector }\end{array}$ & Nutrition, biochemistry, medicine \\
\hline Portugal & No data available & No data available & No data available & No data available & No data available & No data available \\
\hline Romania & $\begin{array}{l}\text { Ministry of Health, supported by the } \\
\text { Institute of Public Health Bucharest } \\
\text { (IPH) }\end{array}$ & $\begin{array}{l}\text { Governmental, } \\
\text { National } \\
\text { Committee of } \\
\text { Nutrition } \\
\text { (in 2008) }\end{array}$ & No data available & Twenty & $\begin{array}{l}\text { Individual expertise, institutional } \\
\text { authority (IPH) }\end{array}$ & $\begin{array}{l}\text { Nutrition, food hygene, public } \\
\text { health, medicine }\end{array}$ \\
\hline $\begin{array}{l}\text { Russian } \\
\text { Federation }\end{array}$ & $\begin{array}{l}\text { Ministry of Health, supported by the } \\
\text { Institute of Nutrition at the Russian } \\
\text { Academy of Medical Sciences }\end{array}$ & $\begin{array}{l}\text { Governmental, } \\
\text { scientific }\end{array}$ & $\begin{array}{l}1982 \text { (previous } \\
\text { publication) }\end{array}$ & Three & $\begin{array}{l}\text { Individual expertise (scientific), } \\
\text { institutional authorities }\end{array}$ & $\begin{array}{l}\text { Nutrition, biochemistry, } \\
\text { medicine, toxicology, } \\
\text { epidemiology, food } \\
\text { technology }\end{array}$ \\
\hline Serbia & Ministry of Labour and Social Policy & $\begin{array}{l}\text { Governmental, expert } \\
\text { group }\end{array}$ & 1993 & Four to five & Individual expertise & $\begin{array}{l}\text { Nutrition, public health, hygiene, } \\
\text { medical ecology, medicine }\end{array}$ \\
\hline Slovakia & Ministry of Health & Governmental & No data available & Two & $\begin{array}{l}\text { Individual expertise, institutional } \\
\text { authority, specific sector, } \\
\text { different forms of knowledge }\end{array}$ & $\begin{array}{l}\text { Nutrition, public health, } \\
\text { medicine, toxicology, } \\
\text { epidemiology, food } \\
\text { technology }\end{array}$ \\
\hline Slovenia & $\begin{array}{l}\text { Ministry of Health, department related } \\
\text { to Public Health }\end{array}$ & Governmental & No data available & Two & $\begin{array}{l}\text { Individual expertise, institutional } \\
\text { authority, specific sector, } \\
\text { different forms of knowledge }\end{array}$ & $\begin{array}{l}\text { Nutrition, public health, } \\
\text { medicine, food technology }\end{array}$ \\
\hline Spain & $\begin{array}{l}\text { Madrid University and Spanish } \\
\text { Society of Community Nutrition } \\
\text { (SENC) }\end{array}$ & $\begin{array}{l}\text { Nutrition society, } \\
\text { expert group }\end{array}$ & No data available & Three & $\begin{array}{l}\text { Individual expertise, institutional } \\
\text { authority }\end{array}$ & Nutrition \\
\hline
\end{tabular}




\begin{tabular}{|c|c|c|c|c|c|c|}
\hline \multirow[b]{2}{*}{$\begin{array}{l}\text { Country/ } \\
\text { organisation/region }\end{array}$} & \multicolumn{6}{|c|}{ Involvement in setting recommendations } \\
\hline & Body responsible & Type of body & Responsible since & Persons involved & Selection criteria & Field of expertise \\
\hline $\begin{array}{l}\text { The former YR } \\
\text { Macedonia }\end{array}$ & $\begin{array}{l}\text { Ministry of Health, supported by } \\
\text { Republic Institute of Health } \\
\text { Protection (in 2001: Macedonian } \\
\text { Association of Physicians) }\end{array}$ & $\begin{array}{l}\text { Working group } \\
(2001)\end{array}$ & No data available & Five (2001) & $\begin{array}{l}\text { Individual expertise, institutional } \\
\text { authority, specific sector, } \\
\text { different forms of knowledge }\end{array}$ & $\begin{array}{l}\text { Nutrition, public health, } \\
\text { biochemistry, medicine, } \\
\text { toxicology, epidemiology, food } \\
\text { technology }\end{array}$ \\
\hline UK & $\begin{array}{l}\text { Department of Health and Food } \\
\text { Standards Agency, supported by } \\
\text { the Scientific Advisory Committee } \\
\text { on Nutrition (SACN) (previously } \\
\text { called Committee on Medical } \\
\text { Aspects of Food and Nutrition } \\
\text { Policy (COMA)) }\end{array}$ & $\begin{array}{l}\text { Governmental, } \\
\text { SACN is an } \\
\text { advisory } \\
\text { committee of } \\
\text { independent } \\
\text { experts }\end{array}$ & 1991 (COMA 1990) & $\begin{array}{l}\text { Thirteen, including } \\
\text { two lay } \\
\text { representatives } \\
\text { (plus ten } \\
\text { observers). } \\
\text { Members must } \\
\text { apply and are } \\
\text { appointed by the } \\
\text { government }\end{array}$ & $\begin{array}{l}\text { Individual expertise, specific } \\
\text { sector, institutional authorities } \\
\text { (COMA (appointed by } \\
\text { ministers), the Health } \\
\text { Education Authority and the } \\
\text { Medical Research Council, } \\
\text { Chief Medical Officers of } \\
\text { England, Scotland, Wales and } \\
\text { Northern Ireland, } \\
\text { representatives of the Ministry } \\
\text { of Agriculture, Fisheries and } \\
\text { Food and the Department of } \\
\text { Health) }\end{array}$ & $\begin{array}{l}\text { Nutrition, public health, } \\
\text { biochemistry, medicine }\end{array}$ \\
\hline $\mathrm{EC}^{*}$ & $\begin{array}{l}\text { European Food Safety Authority, } \\
\text { Scientific Committee for Food }\end{array}$ & Working group & No data available & Nineteen & $\begin{array}{l}\text { Individual expertise, no data } \\
\text { available on other criteria }\end{array}$ & Various \\
\hline WHO/FAO* & WHO and FAO (United Nations) & Expert Consultation & 1973 & No data available & No data available & No data available \\
\hline
\end{tabular}

EC, European Commission; N/A, not applicable.

DACH countries: Germany, Austria and Switzerland.

Nordic countries: Denmark, Finland, Iceland, Norway and Sweden.

All data are based on questionnaire primarily, scientific reports on recommendations secondarily and country-specific key informants in the third place.

*Data from the scientific reports only. 
EU and DACH recommendations, and some adjustments made with reference to the Hungarian population surveys. The committee was not engaged in problem framing, delineation of the criteria for systematic reviews (the type of evidence to be used) and the lengthy process of adjudging the areas of uncertainties on which recommendations are made. In Czech Republic, the few recommendations that exist are also based on international recommendations such as DACH.

Understanding how the process of setting recommendations and their translation into policies varies across types of SAB will help identify some determinants of variation in the final micronutrient-relevant policy approaches across countries. We will provide assessments of transparency of this process and describe problem formulation, evidence gathering, micronutrient recommendations achieved and policy options that are recommended, as well as how these are finally translated into policy across the seven countries in relation to FA, chosen for its salience with regard to fortification as a policy option. Options for mandatory, partly mandatory and voluntary FA fortification attract considerable debate and require considerations of both a political and a scientific nature.

\section{Transparency of the scientific process}

The UK, Norwegian, Danish and DACH SAB endeavour to provide the public with information on some aspects of their workings. The main sources of information are dedicated websites, which host information on reports, meeting minutes, the make-up of the committee and the working groups (names and affiliations), how the committee is organised, stakeholder consultation summaries and, in the UK, a document clarifying the decision-making process for evaluating scientific evidence and recommending nutrient reference values ${ }^{(46)}$.

The main source of information about the NNR is the official publication of the Nordic Council of Ministers $2004^{(47)}$. It lists the selection criteria for the project group, the general approach for the establishment of a recommended daily intake for certain nutrients and the methodological considerations for the evaluation of the available evidence. The evolution of nutrition-based policies in Norway is visible through policy documents (some of them published on official government websites) and the list of stakeholders involved in the process.

The main source for information about micronutrient recommendations in Germany is the official website of the DGE. Information about the composition and affiliations of the working group and of other contributors is provided, as well as press releases related to the publication of the document. Summary tables are provided and the document ${ }^{(48)}$ is available for downloading in the English language.

In the Czech Republic and Hungary, as well as Spain, there is little documentation on the official criteria and process that are used to establish these recommendations.
In each of these countries the fragmented institutional context for the management of food and nutrition public health issues and the low priority ascribed to nutritional matters might explain this lack of transparency.

\section{Fortification policies}

The case of Norway illustrates NNC's shift from public campaign-based education to a recommendation of mandatory fortification in the space of $<10$ years, and a reluctance of the governing bodies to follow through the scientific advice. On two occasions, in 1996 and in 1997, the NNC was tasked with evaluating the needs for FA intake: in 1996, the terms of reference were the evaluation of the FA intake status for the general population, and in 1997, the evidence of the FA intake of women of childbearing age was examined. Committee members included researchers in the area of FA and diet, the Food Authorities, the Norwegian Medicines Agency, the Norwegian Board of Health Supervision and the NNC. The 1996 committee concluded that there was not enough evidence to change the recommendation for the general population and that the advice of the FBDG to increase fruit, vegetable, potato and dark bread intake was sufficient. The 1997 committee recommended an increase in FA intake to $0.4 \mathrm{mg}$ and a recommended daily supplement and FBDG, although fortification of foods with FA was not considered a suitable option to increase intake (since the general population could be at risk of having too high an intake). A subsequent report produced in 2004 by a working group appointed by the NNC - Norwegian Directorate of Health - recommended that mandatory fortification should be considered due to the unsatisfactory results of the current periconceptional FA recommendations; but, as yet, there is no mandatory fortification policy in Norway ${ }^{(49)}$.

A similar case is reported in Denmark. A report on $\mathrm{FA}^{(50)}$ and neural tube defects (NTD) was prepared in 1997 by the National Food Agency in Denmark based on the work of a group of experts within the area. Enrichment as a policy option was discussed, but not recommended. Following the Danish Dietary Survey as well as the creation of a working group of experts for FA in 2003, the committee recommended to the Danish Veterinary and Food Administration policy makers a combined approach of both mandatory fortification and supplementation. Fortification levels were recommended to be low $(0 \cdot 1-0 \cdot 2 \mathrm{mg})$ so as to minimise risk to other population groups. To date, policy makers have not introduced compulsory fortification in Denmark and, instead, as a result of foreign experience, supplementation was upheld as the only viable policy option.

To date, there is no FA food fortification policy in Germany; however, it is currently being considered. Recommendations for the prevention of NTD by FA supplementation were given for the first time in 1994 as common recommendations by five German societies (DGE, German Society of Gynaecology and Obstetrics, German 
Society of Human Genetics, German Society of Paediatrics and Society of Neuropaediatrics), who recommended fortifying selected staple foods, such as bread. The fortification debate continued after the 1998 German National Health Interview and Examination Survey ${ }^{(51)}$. Two SAB worked in parallel on the issue of FA. The final recommendations included three possible policies for FA-fortified foods: mandatory fortification of wheat and rye flour all over the country; voluntary fortification of wheat and rye flour; or voluntary fortification of table and cooking salt. The DGE subsequently established an FA working group, which published a position paper in $2006^{(52)}$ in which mandatory fortification of baking flours with FA was favoured.

The UK national food fortification with FA is currently being considered by Health Ministers. National FA fortification was recommended in a Committee on Medical Aspects of Food Policy (COMA) report in $2000^{(53)}$; yet in 2002, the FSA decided against recommending mandatory fortification to the UK health ministers. This was largely due to stakeholder concerns over health risks in the elderly population and consumer concerns over lack of product choice. In 2007, following a review of evidence since the COMA report, the FSA received a draft report from SACN, which recommended mandatory FA food fortification (of bread and flour) in order to decrease the incidence of NTD-affected pregnancies in the UK. Recommendations also included control over industry voluntary FA fortification and the necessity of clear advice on the use of FA supplements ${ }^{(54)}$. The SACN-updated review of FA fortification allowed stakeholders the opportunity to again discuss mandatory fortification. Following the consultation, some of the difficulties with adopting fortification were identified; however, the FSA adopted mandatory fortification of bread and flour in $2007^{(55)}$ and presented the option to Health Ministers (who have the ultimate decision about fortification) in early $2009^{(56)}$. In order to inform the ministers' final decision on mandatory fortification, in October 2007 the Chief Medical Officer (CMO) of England, on behalf of all the UK CMO, asked SACN to further consider two studies that suggested that FA may increase the risk of colorectal cancer $^{(57,58)}$. In 2009, SACN concluded that the new evidence does not provide a substantial basis to change its previous recommendation; it was only amended to clarify the advice on supplement use. The CMO is expected to advise UK Health Ministers of SACN's recommendation shortly, and Health Ministers will then decide whether to approve mandatory FA fortification in the UK. The timing for this decision is not known.

In Spain, the recommended intake for FA was set by the Spanish Society of Community Nutrition (2005) ${ }^{(59)}$ and included FBDG and supplementation as policy options. Industry has engaged in voluntary fortification of foods although currently there is no coherent effort to estimate the bioavailability of FA in food products, as well as population intake of FA.
In Czech Republic, nutrition recommendations issued in 1989 have been updated with the general nutrition recommendations of the Society for Nutrition of 2004 and recommendations of the Ministry of Health (MZ CR) of 2005; but these do not provide recommendations for total FA intake. Numeric recommendations for FA are defined in regulation ${ }^{(60)}$, which deals with the requirements for food supplements and on foodstuffs fortified with food supplements. At present a proposal for recommended dietary allowances, which also includes numeric recommendations for FA, is being prepared. This proposal is based on international publications (The Safety of Vitamins and Minerals (2002) and Vitamin and Mineral Supplements (2004) by the European Responsible Nutrition Alliance) and the opinion of the Scientific Committee on Food, which proposes adopting the current EU nutrition recommendations ${ }^{(61)}$. It is not clearly defined who in the Czech Republic should be involved in establishing FA recommendations. It is thought that the initiator should be the Ministry of Health together with scientific societies and the professionals in the area of nutrition so that both state-controlled and non-governmental organisations are represented.

In Hungary, reference values have existed since 2006, based on international recommendations and adjusted for the Hungarian population, following a Hungarian Nutritional Survey in 2003-2004. Currently, in Hungary, there is no mandatory FA food fortification. An FA team was created to discuss the survey results; however, no agreement was reached, and mandatory policy is not expected to come into force in the near future. Voluntary fortification is allowed under government policy and legislation, but there is no available database showing details of the foods that are fortified. Voluntary FA bread fortification existed in Hungary, but has since disappeared due to a lack of official support and insufficient health education ${ }^{(62,63)}$. No public stakeholder consultation exercises were set up to aid final decisions on fortification. Consumer issues were considered through the adoption of voluntary fortification, which maintains that consumer choice and nutrition policies are partly visible through policy document press releases and periodical and website publications. However, micronutrient policies are exclusively discussed by scientists, medical doctors and dietitians.

\section{Discussion and conclusions}

The above analysis indicates that across Europe a variety of bodies are responsible for setting micronutrient recommendations, each with different statutory and legal models of operation. Where there are standing SAC, e.g. UK and the Nordic countries, the processes of decision making are publicly reported, and the results of at least some interactions with policy makers and stakeholders are published in the form of consultation reports, meeting minutes and final decisions. Lack of transparent and 
open decision making is characteristic of those countries where there are no dedicated publicly funded and government-supported bodies dealing with nutritional issues. In the countries where there are no standing SAC or dedicated and recognised professional bodies, processes for selecting who is involved in setting recommendations, for determining which issues to focus on and how the science links with public health actions are either non-existent or non-transparent. Spain and Czech Republic are examples of countries where the links between science and regulatory realities are largely unspecified.

In the countries where a standing SAC is created, the selection of experts is carried out by the government; once selected, these committees appear to have a degree of autonomy in choosing the members who will sit on specific working groups or sub-committees. Nevertheless, the process is driven by self-selection, whereby prospective members of standing and working committees must apply to be considered. In the countries without standing committees, experts are drawn from the centres of excellence or institutes with authority and a long history of scientific work in the relevant area (as in the case of Spain, Czech Republic and Hungary), or through membership of professional organisations (e.g. DACH). The case of DACH is indicative of the important role that a strong professional corpus can play in providing vision and strategy, as well as active shaping of the public health agenda. In contrast to the UK/Nordic model, in the German case there is no clear separation between risk assessment and risk management/communication. DGE has a role both in setting NRV and in translating these into FBDG and developing communication strategies of nutritional guidelines. This may be a consequence of a specific public health and risk management context within which recommendations have evolved. Arguably, the situation in the UK has been shaped by public disquiet about the role science plays in policy decision making. The consequent separation of risk assessment from risk management has not been evident in Germany.

Where there is no dedicated SAB (Spain, Czech Republic, Hungary), the impetus for the development of micronutrient recommendations and the associated policies comes from interested specialists in the area. Typically, in these cases, we observe an ad hoc selection of problem areas to consider (e.g. which micronutrients or which population groups) based on specific institutional or individual interests and expertise, the lack of a coherent approach to science informing possible decisions, overreliance on international scientific and political influences and policies that are neither informed by science nor a result of a transparent consultation process. When there is a dedicated $\mathrm{SAB}$ for nutrition, government sets its terms of reference. These are often to evaluate the current micronutrient status in the whole population or a population group, evaluate the existing evidence leading to setting country- and population-specific NRV and to re-evaluate previous recommendations. However, as indicated in the analysis, their terms of reference can sometimes include a more political remit such as providing government with an assessment of feasibility of a particular policy option (although the final decision always rests with the government).

Mandatory fortification of food with FA is recommended by four (UK, Norway, Denmark, Germany) out of seven SAB studied here; however, in most cases it is rejected by governing bodies as either not feasible or too sensitive to pursue. Despite our speculation that the decision made within the dedicated SAC will 'resonate' with government bodies and be more likely to be adopted and translated into policy, we can see that this is not the case, especially in the case of mandatory fortification. The case of fortification, which necessitates considerations of wider socio-political context, illustrates the scope of political considerations performed by some SAC. The case study showed that the science behind the recommendations of mandatory FA fortification is far from conclusive - a frequently voiced concern among scientists and SAC is that excessive exposure to FA may be associated with a number of health risks, whereas ethical considerations play a part in evaluating these risks. Recent expectations to engage with stakeholders in the process of decision making (e.g. through consultations) put a further onus on these bodies to engage in a political process. Scientific uncertainties coupled with the political context in which the SAC operate indicate that the decision for mandating FA fortification is in fact subjected to multiple, often subtle influences.

Extrapolating from the case of FA we suggest that the process of setting micronutrient recommendations is political as well as scientific, and call for greater transparency in the workings of these bodies, in particular of the sources and salience of different types of evidence.

\section{Acknowledgements}

The work reported herein has been carried out within the EURRECA Network of Excellence (www.eurreca.org) which is financially supported by the Commission of the European Communities, specific Research, Technology and Development (RTD) Programme Quality of Life and Management of Living Resources, within the Sixth Framework Programme, contract no. 036196. This report does not necessarily reflect the Commission's views or its future policy in this area. There were no conflicts of interest in the process of conducting and reporting on the current research. L.T. and M.M.R. designed the study. L.T., M.M.R., K.B., L.F.-C., L.D., J.R., A.-M.S., M.H., B.K. and L.F.-A. coordinated data collection for the case studies reported here, analysed and wrote the country-specific case studies on FA recommendations. L.T., R.A.D.-R. and M.M.R. contributed to the design of the questionnaire. R.A.D.-R. coordinated data collection across thirty-five countries. 
L.T. drafted and wrote the manuscript, M.M.R. and J.B. edited the manuscript. All the authors commented on the manuscript The authors would like to acknowledge Lisette C.P.G.M. de Groot, Pieter van 't Veerand and Adriënne E.J.M. Cavelaars for their contribution in designing the questionnaire for data collection. The authors also thank the key informants from the UNU/SCN Network for Capacity Development in Nutrition in Central and Eastern Europe and from other countries listed below for their contribution completing the questionnaire sent out by EURRECA. Key informants in each country are as follows. Albania: Adrian Berisha (Agricultural University of Tirana). Belgium: Stefaan De Henauw (Ghent University). Bosnia and Herzegovina: Aida Filipović Hadziomeragić (Institute of Public Health). Bulgaria: Vesselka Duleva (National Center of Public Health Protection). Croatia: Vedran Poljak (National Institute of Public Health). Czech Republic: Irena Rehurkova (National Institute of Public Health) and Eva Gottvaldova (Ministry of Health). Denmark: Anne Scott (Danish Veterinary and Food Administration); Agnes N. Pedersen and Ellen Trolle (The Danish Fitness and Nutrition Council). Estonia: Sirje Vaask (Tallinn University of Technology, Department of Food Processing) and Katrin Aasvee (National Institute for Health Development). Finland: Kaisa Kukkonen (Food Safety Authority) and Raija Kara (National Nutrition Council, Food Safety Authority). France: Martin Ambroise (Claude Bernard University Medical School, Lyon). Greece: Antonia Trichopoulou (School of Medicine, National and Kapodistrian University of Athens). Hungary: Livia Dömölki (National Association for Consumer Protection in Hungary). Iceland: Elva Gísladóttir (Hólmfríður Porgeirsdóttir Public Health Institute of Iceland). Ireland: Kevin Cashman (University College Cork). Italy: Luca Scalfi (Italian Society of Human Nutrition - SINU). Latvia: Ilze Straume (Ministry of Health). Lithuania: Barzda Albertas (National Nutrition Center) and Algis Abaravicius (Ministry of Health). Montenegro: Ljiljana Zizić, Zorica Djordjević (Institute for Public Health). Netherlands: Caroline Spaaij and Rianne Weggemans (Health Council). Norway: Rønnaug Aarflot Fagerlid (Norwegian Food Safety Authority) and Lars Johansson (Norwegian Directorate of Health). Republic of Macedonia: Zlatanka Dimitrovska (Institute of Health Protection). Republic of Srpska: Dragana Stojisavljević (Public Health Institute of the Republic of Srpska, Medical Faculty Banjaluka, RS/BiH). Romania: Camelia Parvan (Institute of Public Health). Russian Federation: Victor Tutelyan (Institute of Nutrition at Russian Academy of Medical Sciences). Serbia: Maria Glibetić, Mirjana Gurinović and Jasna Tepsić (Institute for Medical Research, Department for Nutrition and Metabolism, University of Belgrade). Slovakia: Iveta Trusková (Slovak Medical University), Igo Kajaba (Research Base of the Slovak Medical University, RB SMU). Slovenia: Fajdiga Turk Vida (Institute of Public Health). Spain: Luis Serra Majem (Department of Clinical Sciences, University of Las Palmas de Gran Canaria). Sweden: Wulf Becker (National Food Administration).
UK: Anja Fragodt (School of Human Sciences, University of Surrey). WHO: Trudy Wijnhoven (WHO Regional Office for Europe).

\section{References}

1. Vorster HH, Murphy SP, Allen LH et al. (2007) Application of nutrient intake values (NIVs). Food Nutr Bull 28, Suppl. 1, 116-122.

2. King JC \& Garza C (2007) Harmonization of nutrient intake values. Food Nutr Bull 28, Suppl. 1, 3-12.

3. Doets E, de Wit LS, Dhonukshe-Rutten RAM et al. (2008) Current micronutrient recommendations in Europe: towards understanding their differences and similarities. Eur J Nutr 47, 17-40.

4. Scientific Committee for Food (1993) Nutrient and Energy Intakes for the European Community. Reports of the Scientific Committee for Food, Thirty First Series. Luxembourg: European Commission; available at http://ec. europa.eu/food/fs/sc/scf/out89.pdf

5. Thuraisingam S, Riddell L, Cook K et al. (2009) The politics of developing reference standards for nutrient intakes: the case of Australia and New Zealand. Public Health Nutr 12, 1531-1539.

6. Pijls L, Ashwell M \& Lambert J (2009) EURRECA - a network of excellence to align European micronutrient recommendations. Food Chem 113, 748-753.

7. Garza C \& Pelletier DL (2007) Dietary guidelines past, present, and future. In Nation's Nutrition, p. 205 [E Kennedy and R Deckelbaum, editors]. Washington, DC: ILSI Press.

8. Brown MB, Lentsch J \& Weingart P (2005) Representation, expertise and the German parliament: a comparison of three advisory institutes. In Democratization of Expertise? Exploring Novel Forms of Scientific Advice in Political Decision-Making, pp. 81-101 [S Maasen and P Weignart, editors]. Dordrecht: Springer.

9. Trübswasser U \& Branca F (2009) Nutrition policy is taking shape in Europe. Public Health Nutr 12, 295-306.

10. Ezrahi Y (1990) The Descent of Icarus. Cambridge, MA: Harvard University Press.

11. Rayner S (2007) The rise of risk and the decline of politics. Environmental Hazard 7, 165-172.

12. Commission of the European Communities (2000) Science, Society and the Citizen in Europe. Commission Working Document SEC(2000) 1973, 14.11.2000. Brussels: European Commission.

13. Walls J, O'Riordan T, Horlick-Jones T et al. (2005) The meta-governance of risk and new technologies: GM crops and mobile telephones. $J$ Risk Res 8, 635-661.

14. Agar J (2008) What happened in the sixties? Br J Hist Sci $\mathbf{4 1}$, 567-600.

15. Packer K (2007) Defra's Scientific Advisory Committees and Public Engagement. KP Draft Defra Report 1.3. London: Council for Science and Technology.

16. Jackson T \& Michaelis L (2003) Policies for Sustainable Consumption. London: Sustainable Development Commission.

17. Irwin A \& Michael M (2003) Science, Social Theory \& Public Knowledge. Maidenhead: McGraw-Hill International.

18. Commission of the European Communities (2001) European Governance: A White Paper. COM(2001) 428 final, 25.7.2001. Brussels: European Commission.

19. Wardman J \& Lofstedt RE; Advisory Group on Risk Communications (2009) European Food Safety Authority Risk Communication Annual Review. EFSA/AGRC/ 29MAY2009/AGENDA ITEM 7.3. Parma: EFSA. 
20. European Food Safety Authority (2009) Transparency in Risk Assessment - Scientific Aspects. Guidance of the Scientific Committee on Transparency in the Scientific Aspects of Risk Assessments carried out by EFSA. Part 2: General Principles. The EFSA Journal 1051, 1-22.

21. Stigoe J \& Wilsdon J (2006) Engagement, Evidence and Expertise. Balancing Different Forms of Knowledge in Regulatory Decision-Making. A Discussion Paper for the Food Standards Agency. DEMOS Draft 2.0, 14 September. London: FSA.

22. Solesbury W (2001) Evidence Based Policy: Whence it Came and Where it's Going. ESRC UK Centre for Evidence Based Policy and Practice, Working Paper no. 1. London: Queen Mary, University of London; available at http:// www.kcl.ac.uk/content/1/c6/03/45/84/wp1.pdf

23. Glynn S, Flanagan K, Keenan M et al. (2001) Science and Governance: Describing and Typifying the Scientific Advice Structure in the Policy Making Process - a Multinational Study. Report EUR 19830 EN. Seville: European Commission Joint Research Centre (DG JRC), Institute for Prospective Technological Studies.

24. Jasanoff S (2005) Judgment under siege: the three-body problem of expert legitimacy. In Democratization of Expertise? Exploring Novel Forms of Scientific Advice in Political Decision-Making, pp. 209-224 [S Maasen and P Weingart, editors]. Dordrecht: Springer.

25. Maasen S \& Weigart P (editors) (2005) Democratization of Expertise? Exploring Novel Forms of Scientific Advice in Political Decision-Making. Sociology of the Sciences Yearbook, vol. 24. Springer.

26. Evans R \& Collins H (2002) The third wave of science studies: studies of expertise and experience. Soc Stud Sci 32, 235-296.

27. Willison DJ \& McLeod SM (1999) The role of research evidence in pharmaceutical policy making: evidence when necessary but not necessarily evidence. J Eval Clin Pract $\mathbf{5}$, 243-249.

28. Weiss C (1979) The many meanings of research utilization. Public Adm Rev 39, 426-431.

29. Wynne B (2002) Risk and environment as legitimatory discourses of technology: reflexivity inside out? Curr Sociol 50, 459-477.

30. Dobrow MJ, Goel V, Lemieux-Charles L et al. (2006) The impact of context on evidence utilization: a framework for expert groups developing health policy recommendations. Soc Sci Med 63, 1811-1824.

31. Nunn R (2008) A network model of expertise. Bull Sci Technol Soc 28, 414-427.

32. Hilgartner S (2000) Science on Stage: Expert Advice as Public Drama. Stanford, CA: Stanford University Press.

33. Jasanoff S (editor) (2004) States of Knowledge: The CoProduction of Science and Social Order. London: Routledge.

34. Blok A (2007) Experts on public trial: on democratizing expertise through a Danish consensus conference. Public Underst Sci 16, 163-182.

35. Stirling A (2005) Opening up or closing down: analysis, participation and power in the social appraisal of technology. Jpn J Sci Technol Soc 14, 63-83.

36. Horlick-Jones $\mathrm{T}$ (2005) Informal logics of risk: contingency and modes of practical reasoning. J Risk Res $\mathbf{8}, 253-272$.

37. Lowndes V, Pratchett L \& Stoker G (2001) Trends in public participation: Part 1 - local government perspectives. Public Adm 79, 205-222.

38. Morton A, Airoldi M \& Phillips D (2009) Nuclear risk management on stage: a decision analysis perspective on the UK's Committee on Radioactive Waste Management. Risk Anal 29, 764-779.

39. Armstrong R, Waters E, Roberts $\mathrm{H}$ et al. (2006) The role and theoretical evolution of knowledge translation and exchange in public health. $J$ Public Health 28, 384-389.
40. Wentholt MTA, Rowe G, König A et al. (2009) The views of key stakeholders on an evolving food risk governance framework: results from a Delphi study. Food Policy 34, 539-548.

41. Renn O (2004) The challenge of integrating deliberation and expertise: participation and discourse in risk management. In Risk Analysis and Society: An Interdisciplinary Characterization of the Field, pp. 289-366 [TL McDaniels and MJ Small, editors]. Cambridge: Cambridge University Press.

42. Stirling A (2008) Science, precaution and the politics of technological risk. Converging implications in evolutionary and social scientific perspectives. Ann N Y Acad Sci 1128, 95-110.

43. Dobrow M, Goel V \& Upshur REG (2004) Evidence-based health policy: context and utilisation. Soc Sci Med 58, 207-217.

44. Guston DH (2000) Boundary organisations in environmental policy and science: an introduction. Sci Technol Human Values 26, 399-408.

45. Cash D, Clark W, Alcock F et al. (2002) Salience, Credibility, Legitimacy and Boundaries: Linking Research, Assessment and Decision Making. KSG Working Papers Series no. RWP02-046. Cambridge, MA: John F. Kennedy School of Government, Harvard University; available at http://papers.ssrn.com/sol3/papers.cfm?abstract_id=372280

46. Scientific Advisory Committee for Nutrition (2002) Paper for discussion: A Framework for Evaluation of Evidence that Relates Food and Nutrients to Health. http://www. sacn.gov.uk/pdfs/sacn_02_02a.pdf

47. Nordic Council of Ministers (2004) Nordic Nutrition Recommendations 2004 - Integrating Nutrition and Physical Activity, 4th ed. Copenhagen: Nordic Council of Ministers.

48. German Nutrition Society, Austrian Nutrition Society, Swiss Society for Nutrition Research \& Swiss Nutrition Association (2000) Referenzwerte fur Die Nabrstoffzufubr (Reference Values for Nutrient Intake), 1st ed. Frankfurt/Main: Umschau Braus.

49. Daltveit AK (2007) Report on periconceptional folic acid supplementation in Norway. Special EUROCAT Report December 2007 Survey of Folic Acid Policy and Practice in European Countries. http://www.eurocat.ulster.ac.uk/pdf/ NTD/December-2007/Norway.pdf

50. Christiansen M (1997) Report on periconceptional folic acid supplementation. http://www.eurocat.ulster.ac.uk/ pdf/NTD/December-2007/Denmark.pdf

51. Robert Koch Institute (2004) Modell zu Auswirkungen einer Mehlanreicherung mit Folsäure auf die Versorgungssituation in Deutschland. Epidemiologisches Bulletin 34, 281-283.

52. German Nutrition Society (2006) Position paper on mandatory fortification of baking flours with folic acid. Emährungs-Umschau 53, Heft 11, S424-S429 (Teil 1) and Heft 12, S468-S479 (Teil 2).

53. Committee on Medical Aspects of Food Policy (2000) Folic Acid and the Prevention of Disease. Department of Health. Report on Health and Social Subjects no. 50. London: TSO.

54. Scientific Advisory Committee for Nutrition (2006) Folate and disease prevention. http://www.sacn.gov.uk/pdfs/ folic_sacn_06_01.pdf

55. Food Standards Agency (2007) Options for improving folate intakes of women of reproductive age and preventing neural tube defects. Board Paper, Agenda Item 3.1, 17 May 2007. http://www.food.gov.uk/multimedia/pdfs/ fsa070504rev.pdf

56. Food Standards Agency (2009) Folic acid fortification. http://www.food.gov.uk/healthiereating/folicfortification/

57. Cole BF, Baron JA, Sandler RS et al. (2007) Folic acid for the prevention of colorectal adenomas. JAMA 297, 2351-2359.

58. Mason JB, Dickstein A, Jacques PF et al. (2007) A temporal association between folic acid fortification and an increase in colorectal cancer rates may be illuminating important 
biological principles: a hypothesis. Cancer Epidemiol Biomarkers Prev 16, 1325-1329.

59. Sociedad Española de Nutrición Comunitaria (2005) Guía de la Alimentación Saludable. Madrid: Editorial Everest.

60. Ministry of Health of the Czech Republic (2004) Decree 446/ 2004 Coll., Laying down the requirements for food supplements and for enriching food with diet supplements, as amended.

61. Commission of the European Communities (1993) Nutrient and energy intakes for the European Community (Opinion expressed on 11 December 1992). Reports of the Scientific Committee for Food (Thirty-first Series). Luxembourg: Directorate-General Industry, European Commission.

62. Sandor (2007) Report on periconceptional folic acid supplementation for Hungary. EUROCAT special report. http://www.eurocat.ulster.ac.uk/pdf/NTD/December-2007/ Hungary.pdf

63. Czeizel AE \& Kokeny M (2002) Bread is fortified with folic acid in Hungary. BMJ 325, 391. 